\title{
Morphology and molecular phylogeny of three new deep-sea species of Chrysogorgia (Cnidaria, Octocorallia) from seamounts in the tropical Western Pacific Ocean
}

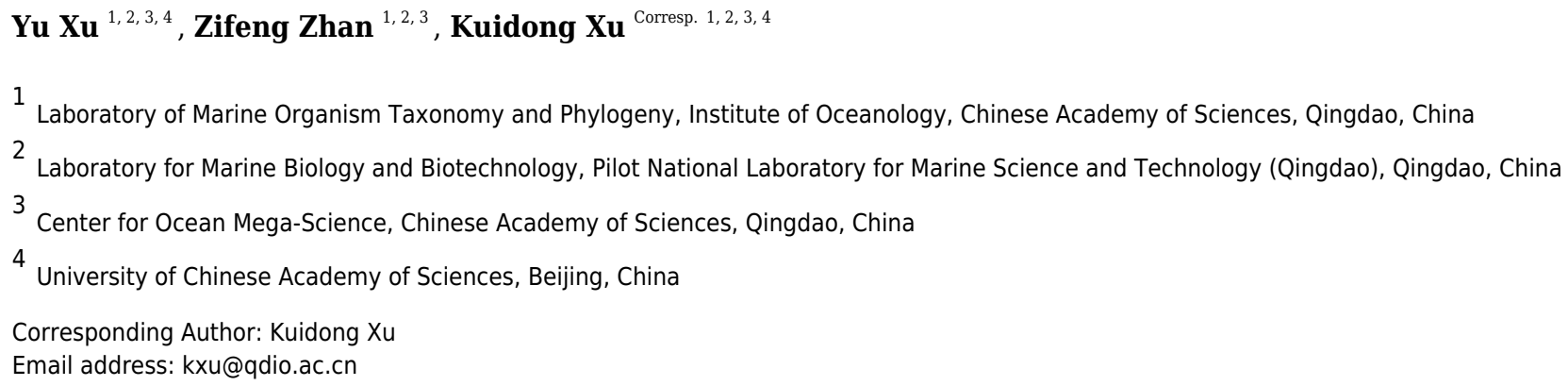

Three new species of Chrysogorgia were discovered from seamounts in the tropical Western Pacific Ocean. Chrysogorgia dendritica sp. nov. and Chrysogorgia fragilis sp. nov. were collected from the Kocebu Guyot of the Magellan Seamount chain with the water depth of 1,821 m and 1,279-1,321 m, respectively, and Chrysogorgia gracilis sp. nov. was collected from a seamount adjacent to the Mariana Trench with the water depth of $298 \mathrm{~m}$. They all belong to the Chrysogorgia "group A, Spiculosae" with rods distributed in body wall and tentacles, and differ from all congeners except $C$. abludo Pante \& Watling, 2012 by having a tree-shaped colony (vs. bottlebrush-shaped, planar or biflabellate). Chrysogorgia dendritica sp. nov. is unique in having a monopodial stem, the $1 / 3 \mathrm{~L}$ branching sequence and the amoeba-shaped sclerites (sclerites branched toward to many directions) at the body bases of polyps. Chrysogorgia fragilis sp. nov. is most similar to $C$. abludo, but differs by the regular $1 / 3 \mathrm{~L}$ branching sequence and elongate flat scales in coenenchyme. Chrysogorgia gracilis sp. nov. is easily separated from congeners by the $1 / 4 \mathrm{~L}$ branching sequence, the absence of sclerites in the basal body wall, and the very sparse scales in coenenchyme. Based on the phylogenetic and genetic distance analyses of mtMutS gene, all the available Chrysogorgia species were separated into two main groups: one includes $C$. binata, $C$. cf. stellata and $C$. chryseis, which have two or more fans emerging from a short main stem (bi- or multi-flabellate colony); the other one includes all the species with the branching patterns as a single ascending spiral (clockwise or counterclockwise, bottlebrush-shaped colony), a fan (planar colony) and a bush of branches perched on top of a long straight stem (tree-shaped colony). Additionally, the tree-shaped colony represents a new branching pattern in Chrysogorgia, and therefore we extend the generic diagnosis. 
1 Morphology and molecular phylogeny of three new deep-sea species of Chrysogorgia

2 (Cnidaria, Octocorallia) from seamounts in the tropical Western Pacific Ocean

3

4

5

6

7

8

9

Yu Xu ${ }^{1,2,3,4}$, Zifeng Zhan ${ }^{1,2,3}$, Kuidong $\mathrm{Xu}^{1,2,3,4}$

${ }^{1}$ Laboratory of Marine Organism Taxonomy and Phylogeny, Institute of Oceanology, Chinese Academy of Sciences, Qingdao, Shandong, China

${ }^{2}$ Laboratory for Marine Biology and Biotechnology, Pilot National Laboratory for Marine Science and Technology (Qingdao), Qingdao, Shandong, China

${ }^{3}$ Center for Ocean Mega-Science, Chinese Academy of Sciences, Qingdao, Shandong, China

${ }^{4}$ University of Chinese Academy of Sciences, Beijing, China

Corresponding Author: Kuidong Xu

7 Nanhai Rd., Qingdao, Shandong, 266071, China

Email address: kxu@qdio.ac.cn

\section{Abstract}

Three new species of Chrysogorgia were discovered from seamounts in the tropical Western Pacific Ocean. Chrysogorgia dendritica sp. nov. and Chrysogorgia fragilis sp. nov. were collected from the Kocebu Guyot of the Magellan Seamount chain with the water depth of 1,821 $\mathrm{m}$ and 1,279-1,321 m, respectively, and Chrysogorgia gracilis sp. nov. was collected from a seamount adjacent to the Mariana Trench with the water depth of $298 \mathrm{~m}$. They all belong to the Chrysogorgia "group A, Spiculosae" with rods distributed in body wall and tentacles, and differ from all congeners except C. abludo Pante \& Watling, 2012 by having a tree-shaped colony (vs. bottlebrush-shaped, planar or biflabellate). Chrysogorgia dendritica sp. nov. is unique in having a monopodial stem, the $1 / 3 \mathrm{~L}$ branching sequence and the amoeba-shaped sclerites (sclerites branched toward to many directions) at the body bases of polyps. Chrysogorgia fragilis sp. nov. is most similar to C. abludo, but differs by the regular $1 / 3 \mathrm{~L}$ branching sequence and elongate flat scales in coenenchyme. Chrysogorgia gracilis sp. nov. is easily separated from congeners by the $1 / 4 \mathrm{~L}$ branching sequence, the absence of sclerites in the basal body wall, and the very sparse scales in coenenchyme. Based on the phylogenetic and genetic distance analyses of mtMutS gene, all the available Chrysogorgia species were separated into two main groups: one includes $C$. binata, C. cf. stellata and C. chryseis, which have two or more fans emerging from a short main stem (bi- or multi-flabellate colony); the other one includes all the species with the branching patterns as a single ascending spiral (clockwise or counterclockwise, bottlebrush-shaped colony), a fan (planar colony) and a bush of branches perched on top of a long straight stem (tree-shaped colony). Additionally, the tree-shaped colony represents a new branching pattern in Chrysogorgia, and therefore we extend the generic diagnosis.

Keywords Anthozoa, Chrysogorgiidae, Chrysogorgia dendritica, Chrysogorgia fragilis, 
42

43

44

45

46

47

48

49

50

51

52

53

54

55

56

57

58

59

60

61

62

63

64

65

66

67

68

69

70

71

72

73

74

75

76

77

78

79

80

81

Chrysogorgia gracilis, taxonomy

\section{Introduction}

The genus Chrysogorgia Duchassaing \& Michelotti, 1864 contains 72 species distributed in the world oceans, with water depths ranging from $10 \mathrm{~m}$ to $4492 \mathrm{~m}$ (Watling et al., 2011; Pante et al., 2012; Cairns, 2018; Xu et al., 2019). Three branching forms have been recognized in the colonies of the genus: a single ascending spiral (clockwise or counterclockwise) producing a bottlebrush shape, a single fan (planar colony) and two fans emerging from a short main stem (biflabellate colony) (Pante \& Watling, 2012; Cordeiro et al., 2015). Based on the shapes of rods or scales in the body wall and tentacles, a rough grouping has been built for the separation of Chrysogorgia species. Versluys (1902) divided the genus Chrysogorgia into three groups, which were summarized by Cairns (2001) as "group A, Spiculosae", "group B, Squamosae aberrantes", and "group C, Squamosae typicae". Cordeiro et al. (2015) supplemented the fourth group "group D, Spiculosae aberrantes", which contains only the species C. upsilonia Cordeiro, Castro \& Pérez, 2015.

While studying the benthic diversity in the tropical Western Pacific Ocean, we collected four specimens of Chrysogorgia. Based on morphological and phylogenetic analyses, we describe these specimens as three new species: $C$. dendritica sp. nov., $C$. fragilis sp. nov. and $C$. gracilis $\mathrm{sp}$. nov. Their genetic distances and single mutations on mtMutS as well as phylogenetic relationships within Chrysogorgia species are discussed.

\section{Materials \& Methods}

\section{Specimen collection and morphological examination}

Specimens were obtained by the remotely operated vehicle (ROV) FaXian (Discovery) from an unnamed seamount (temporarily named as M2) adjacent to the Mariana Trench and the Kocebu

Guyot in the Magellan Seamounts in the tropical Western Pacific Ocean during the cruises of the R/V KeXue (Science) in 2016 and 2018 (Fig. 1). These specimens were photographed in situ before sampled, photographed on board and then stored in $75 \%$ ethanol after collection. Some branches were detached and stored at $-80^{\circ} \mathrm{C}$ for molecular analysis.

The general morphology and anatomy were examined by using a stereo dissecting microscope. The sclerites of the polyps and branches were isolated by digestion of the tissues in sodium hypochlorite, and then were washed with deionized water repeatedly. Polyps and sclerites were air-dried and mounted on carbon double adhesive tape and coated for the Scanning Electron Microscope (SEM) to investigate their structure. SEM scans were obtained and the optimum magnification was chosen for each kind of sclerites by using TM3030Plus SEM.

The morphological terminology follows Bayer et al. (1983), with which we coin the following new terms to describe the shape of sclerites. Tree-shaped colony: a bush of branches perched on top of a long straight stem, forming a tree shape. Example: Chrysogorgia dendritica sp. nov. (Fig. 2A). Amoeba-shaped sclerite: sclerites branched toward to many directions, varied in shape like an amoeba. Example: Chrysogorgia dendritica sp. nov. (Fig. 3C). 
82

83

84

85

86

87

88

89

90

91

92

93

94

95

96

97

98

99

100

101

102

103

104

105

106

107

108

109

110

111

112

113

114

115

116

117

118

119

120

121

The type specimens of the three new species have been deposited in the Marine Biological Museum of Chinese Academy of Sciences (MBMCAS) at Qingdao, China.

\section{DNA extraction and sequencing}

Total genomic DNA was extracted from the polyps of each specimen using the TIANamp Marine Animal DNA Kit (Tiangen Bio. Co., Beijing, China) following the manufacturer's instructions. PCR amplification for the mitochondrial genomic region 5'-end of the DNA mismatch repair protein - mutS - homolog (mtMutS) was conducted using primers AnthoCorMSH (5'-AGGAGAATTATTCTAAGTATGG-3'; Herrera et al., 2010) and Mut3458R (5'-TSGAGCAAAAGCCACTCC-3'; Sánchez et al., 2003). PCR reactions were performed using I-5 ${ }^{\mathrm{TM}} 2 \times$ High-Fidelity Master Mix DNA polymerase (TsingKe Biotech, Beijing, China). The amplification cycle conditions were as follow: denaturation at $98^{\circ} \mathrm{C}$ for 2 min, followed by 32 cycles of denaturation at $98^{\circ} \mathrm{C}$ for $20 \mathrm{~s}$, annealing at $50^{\circ} \mathrm{C}$ for $20 \mathrm{~s}$, extension at $72^{\circ} \mathrm{C}$ for $15 \mathrm{~s}$, and a final extension step at $72^{\circ} \mathrm{C}$ for $2 \mathrm{~min}$. PCR purification and sequencing were performed by TsingKe Biological Technology (TsingKe Biotech, Beijing, China).

\section{Genetic distance and phylogenetic analyses}

The mtMutS may be the most variable mitochondrial gene in octocorals (Herrera et al., 2010; McFadden et al., 2011; Li et al., 2017), and we selected this marker for molecular identification and phylogenetic analyses. All the available mtMutS sequences of Chrysogorgia spp. and the out-group species from related chrysogorgiid genera were downloaded from GenBank. The sequences from duplicate isolates or without associated publications or named Chrysogorgia sp. or containing sequencing errors (marked with " $\mathrm{n}$ " or " $\mathrm{y}$ " in the original sequences) were omitted from the molecular analyses. To correct possible mistakes, all the selected sequences were visually inspected, and translated to amino acids (AA) to insure all the AA sequences not including stop codons and suspicious substituteions. The nucleotide and AA sequences were aligned using MAFFT v.7 (Katoh \& Standley, 2013) with the G-INS-i algorithm. With the guidance of the AA alignment, the nucleotide alignment was refined using BioEdit v7.0.5 (Hall, 1999), and only the nucleotide alignment was used in the subsequent analyses. Genetic distances, calculated as uncorrected " $p$ " distances within each species and among species, were estimated using MEGA 6.0 (Tamura et al., 2013).

For the phylogenetic analyses, only one sequence was randomly selected from the conspecific sequences without genetic divergence. The evolutionary model GTR $+\mathrm{G}$ was the best-fitted model for mtMutS, selected by AIC as implemented in jModeltest2 (Darriba et al., 2012). Maximum likelihood (ML) analysis was carried out using PhyML-3.1 (Guindon et al., 2010). For the ML bootstraps, we consider values $<70 \%$ as low, $70-94 \%$ as moderate and $\geqslant 95 \%$ as high following Hillis \& Bull (1993). Node support came from a majority-rule consensus tree of 1000 bootstrap replicates. Bayesian inference (BI) analysis was carried out using MrBayes v3.2.3 (Ronquist \& Huelsenbeck, 2003) on CIPRES Science Gateway. Posterior probability was 
122 estimated using four chains running 10000000 generations sampling every 1000 generations.

123 The first $25 \%$ of sampled trees were considered burn-in trees. Convergence was assessed by

124 checking the standard deviation of partition frequencies $(<0.01)$, the potential scale reduction

125 factor (ca. 1.00), and the plots of log likelihood values (no obvious trend was observed over

126 time). For the Bayesian posterior probabilities, we consider values $<0.95$ as low and $\geq 0.95$ as

127 high following Alfaro et al. (2003). The GenBank accession numbers of the mtMutS sequences

128 were listed next to the species names in the phylogenetic tree.

129

130

\section{ZooBank registration}

131

132

The electronic version of this article in Portable Document Format (PDF) will represent a

133 published work according to the International Commission on Zoological Nomenclature (ICZN), hence the new names contained in the electronic version are effectively published under that Code from the electronic edition alone. This published work and the nomenclatural acts it contains have been registered in ZooBank, the online registration system for the ICZN. The ZooBank Life Science Identifiers (LSIDs) can be resolved and the associated information viewed through any standard web browser by appending the LSID to the prefix http://zoobank.org/. The LSID for this publication is: urn:Isid:zoobank.org:pub:00D5E053-EFF8-4142-8D16AAFC17D028E2. The online version of this work is archived and available from the following digital repositories: PeerJ, PubMed Central, and CLOCKSS.

\section{Results}

Class Anthozoa Ehrenberg, 1834

Subclass Octocorallia Haeckel, 1866

147

Order Alcyonacea Lamouroux, 1812

Chrysogorgia dendritica sp. nov. (Figs. 2 and 3; Table 1)

152 urn:Isid:zoobank.org:act:F0050AD3-9E65-4B03-8D26-2C687018DCAD

Holotype. MBM286354, station FX-Dive $178\left(17^{\circ} 20.18^{\prime}\right.$ N, $\left.152^{\circ} 41.85^{\prime} E\right)$, Kocebu Guyot, depth 1,821 m, 12 April 2018. GenBank accession number: MN510469.

Diagnosis. Chrysogorgia "group A, Spiculosae" with a long monopodial stem and a branching part on the top. Branching sequence 1/3L. Branches nearly perpendicular to stem, subdivided dichotomously. Polyps with a long neck and an expanded base. Rods and spindles in tentacles and polyp neck coarse with many warts. Scales and rare plates at polyp body base flat and amoeba-shaped. Scales in coenenchyme thin with irregular edges. 
163 branching sequence $1 / 3 \mathrm{~L}$. The whole stem monopodial from bottom to top with lateral branches

164

165

166

167

168

169

170

171

172

173

174

175

176

177

178

179

180

181

182

183

184

185

186

187

188

189

190

191

192

193

194

195

196

197

198

199

200

201

202

producing on the top. Stem surface almost smooth with a strong golden metallic luster, about 2 $\mathrm{mm}$ in diameter at base (Figs. 2A, 2B). Branches subdivided dichotomously, up to seventh order, most broken after collection. Distance between adjacent branches $16-22 \mathrm{~mm}$, and orthostiche interval 50-55 mm. First branch internodes $15-20 \mathrm{~mm}$ long, with the terminal branchlets up to $50 \mathrm{~mm}$. Polyps with a long neck and an expanded base, about $3 \mathrm{~mm}$ long and $2 \mathrm{~mm}$ wide at bases, composed of one or two on the first internodes, one to five in middle internodes, and up to six in terminal branchlets (Figs. 2C, 2D). No polyps on main axis internodes. Golden eggs often occurred at the expanded bases.

Rods longitudinally arranged in the back of tentacles, occasionally branched, with many small warts on surface, measuring $77-330 \times 15-34 \mu \mathrm{m}$ (Figs. $2 \mathrm{E}, 3 \mathrm{H}-3 \mathrm{M}$ ). Sclerites rarely extend into the pinnules, which are otherwise sclerite-free. Spindles and rods longitudinally arranged in the long polyp neck, slender with many small warts on surface, usually slightly curved, measuring 193-800 $\times 25-56 \mu \mathrm{m}$ (Figs. 3A-3G). Scales and rare plates transversely and crosswise arranged at body base, flat and amoeba-shaped with irregular edges, measuring 69$248 \times 11-79 \mu \mathrm{m}$ (Figs. 3N-3X). Scales of coenenchyme sparse, flat and lobed with irregular edges, measuring 68-268 $\times 10-70 \mu \mathrm{m}$ (Figs. 3Y-3GG).

Type locality. Kocebu Guyot in the Magellan Seamount chain with water depth of 1,821 m. Etymology. The Latin adjective dendriticus (dendritic) refers to the dendritic shape of the colony. Distribution and Habitat. Found only on the Kocebu Guyot, where the colony attached to a died sponge (Fig. 2A). The water temperature was about $2.31^{\circ} \mathrm{C}$ and the salinity about 35.8 psu. Remarks. Chrysogorgia dendritica sp. nov. has a monopodial stem (Fig. 2B), which makes it appear to be a member of the chrysogorgiid genus Metallogorgia Versluys, 1902. However, the new species is characterized by a series of features matching the genus Chrysogorgia Duchassaing \& Michelotti, 1864. These include the flexible branches, dichotomously subdivided branches not forming a sympodia, relatively large polyp with an expanded base and a narrow neck, and well differentiated coenenchyme usually with more sclerites. The new species also resembles to the genus Pseudochrysogorgia Pante \& France, 2010 in the monopodial stem, but differs by the obviously different polyps and the absence of ornamented sclerites. Our phylogenetic analysis (see below) supports this assignment as well. Chrysogorgia dendritica $\mathrm{sp}$. nov. is distinctly different from congeners by its unique monopodial stem and the amoebashaped sclerites at the body bases.

Chrysogorgia fragilis sp. nov. (Figs. 4 and 5; Table 1) urn:1sid:zoobank.org:act:562CFDA7-88F5-4D81-8FE5-BDE1F56A3EEC

Holotype. MBM286351, station FX-Dive $172\left(17^{\circ} 23.64^{\prime} \mathrm{N}, 153^{\circ} 6.07^{\prime} \mathrm{E}\right)$, Kocebu Guyot, depth 1,321 m, 1 April 2018. GenBank accession number: MN510470.

Paratype. MBM286352, station FX-Dive $173\left(17^{\circ} 28.12^{\prime} \mathrm{N}, 153^{\circ} 10.07^{\prime} \mathrm{E}\right)$, Kocebu Guyot, depth 1,279 m, 7 April 2018.

Peer) reviewing PDF | (2020:01:44705:1:1:NEW 25 Feb 2020) 
203 Diagnosis. Chrysogorgia "group A, Spiculosae" with a long unbranched stem and a sympodial 204 branching part with $1 / 3 \mathrm{~L}$ branching sequence on the top. Branches subdivided dichotomously, up 205 to fifth order. Polyps with an expanded base and a slender neck. Rods and spindles of the polyp 206 neck and tentacles long and coarse, with many warts on surface. Scales at polyp body base 207 elongated and thick, rarely branched. Scales in coenenchyme flat and elongated with irregular 208 edges.

209 Description. Specimen of holotype about $55 \mathrm{~cm}$ in height excluding the holdfast. Colony tree210 shaped, composed of a sympodial branching part on the top and a fragile, slender and 211 unbranched stem about $35.5 \mathrm{~cm}$ long and $1.5 \mathrm{~mm}$ in diameter at base (Fig. 4C). Stem surface 212 almost smooth with a few scars and aeruginous metallic luster, and sometimes covered with a 213 layer of pink mucous membrane. Branching part produced a slightly zigzag pattern at the top 214 portion with branching sequence $1 / 3 \mathrm{~L}$. Branches subdivided dichotomously, nearly 215 perpendicular to the axis, up to fifth order, most broken after collection. Distance between 216 adjacent branches and the first branch internodes both 15-22 $\mathrm{mm}$ long, orthostiche interval 50$21765 \mathrm{~mm}$, and the terminal branches up to $75 \mathrm{~mm}$. Polyps with a long neck and an expanded body 218 base, 2-4 mm long, 1-2 $\mathrm{mm}$ wide at base, with the neck up to $2 \mathrm{~mm}$ long and less than $1 \mathrm{~mm}$ 219 wide (Figs. 4E - 4I). Up to two polyps on the first internodes, two to four in middle internodes, 220 up to ten in terminal branchlets. No polyp on main axis internodes. Golden eggs present in

221

222

223

224

225

226

227

228

229

230

231

232

233

234

235

236

237

238

239

240

241

242 expanded body bases. Polyps pink immediately after collection, color gradually faded in alcohol.

Rods longitudinally arranged in the back of the tentacles, rarely branched, with many small warts on surface, measuring 105-442 × 14-50 $\mu \mathrm{m}$ (Figs. 4G, 4I, 5A-5G). Rare sclerites extend into the pinnules, and pinnules free of sclerites. Spindles and rods longitudinally arranged in the polyp neck, slender with many small warts on surface, sometimes with one or two sharp ends, measuring 170-600 × 17-62 $\mu \mathrm{m}$ (Figs. $4 \mathrm{H}, 5 \mathrm{H}-5 \mathrm{~L}$ ). Scales longitudinally and transversally arranged at base of expanded polyp body, elongated with a few warts and irregular edges, sometimes branched, thicker and wider than those in coenenchyme, measuring 144-551 × 34$106 \mu \mathrm{m}$ (Figs. 4H, 5M-5V). Scales of coenenchyme flat and elongate, rarely with distinctly irregular edges, measuring $122-435 \times 28-83 \mu \mathrm{m}$ (Figs. $5 \mathrm{~W}-5 \mathrm{EE}$ ).

Variation of Paratype. Specimen $65 \mathrm{~cm}$ in height with unbranched stem about $35 \mathrm{~cm}$ long and $1 \mathrm{~mm}$ across at base (Fig. 4D). Branching part relatively longer and more zigzagging.

Type locality. Kocebu Guyot in the Magellan Seamount chain with water depths of 1,279-1,321 $\mathrm{m}$.

Etymology. The Latin adjective fragilis (fragile) refers to the fragile stem and branches of the species.

Distribution and habitat. Found only on the Kocebu Guyot in the Magellan Seamount chain. Colonies attached to rocky substrate. The holotype was attached with an egg-shaped structure and the paratype with an individual of the crustacean genus Galathea Fabricius, 1793 (Figs. 4A, 4B). The water temperature was about $3.2^{\circ} \mathrm{C}$ and the salinity about 35.8 .

Remarks. Chrysogorgia fragilis sp. nov. belongs to the "group A, Spiculosae" with an unusual branching sequence of 1/3L, with which it is similar to Chrysogorgia midas Cairns, 2018 and $C$. 
243 dendritica sp. nov. However, the new species differs distinctly from C. midas Cairns, 2018 by

244 the tree-shaped colony (vs. bottlebrush-shaped), wider orthostiche interval (50-65 mm vs. 12-18

$245 \mathrm{~mm})$, larger polyps $(2.0-4.0 \mathrm{~mm}$ vs. $1.1 \mathrm{~mm})$, and the presence of various shapes of scales at the

246 body bases (vs. absence). Chrysogorgia fragilis sp. nov. is also similar to C. abludo Pante \&

247 Watling, 2012 and C. averta Pante \& Watling, 2012, two species found in the north-western

248 Atlantic Ocean, in possessing the wide orthostiche interval and long and straight unbranched

249 stem. However, the new species is easily separated from C. averta by the tree-shaped colony (vs.

250 bottlebrush-shaped). It differs from C. abludo by the regular 1/3L branching sequence (vs.

251 irregular) and elongate flat scales in coenenchyme (vs. small rugged scales) (Table 1).

252 Chrysogorgia fragilis sp. nov. differs from $C$. dendritica sp. nov. by a sympodial branching part

253 (vs. monopodial) and relatively regular scales at the body bases (vs. amoeba-shaped).

254

255

256

257

258

259

260

261

262

263

264

265

266

267

268

269

270

271

272

273

274

275

276

277

278

279

280

281

282

Chrysogorgia gracilis sp. nov. (Figs. 6 and 7; Table 1)

urn:lsid:zoobank.org:act:F557CE43-D43C-4E5F-86C1-3EFE330A9443

Holotype: MBM286350, station FX-Dive $57\left(11^{\circ} 18.34^{\prime} \mathrm{N}, 139^{\circ} 21.43^{\prime} \mathrm{E}\right)$, an unnamed seamount (temporarily named as M2) adjacent to the Mariana Trench, depth 298 m, 23 March 2016. GenBank accession number: MN510472.

Diagnosis: Chrysogorgia "group A, Spiculosae" with a long unbranched stem and a sympodial branching part emanating in a regular 1/4L spiral on the top. Stem and branches slender, with branches subdivided dichotomously. Terminal branchlets gracile and somewhat whip-like. Polyps small and thin, no more than $1.5 \mathrm{~mm}$ long, located on one side of branches. Rods and rodlike scales slender and abundant in tentacles and at the bases of tentacles. No sclerites at polyp body base. Scales elongated, rare to absent in coenenchyme. Mesozooids dense along the internodes of top stem and the bases of branches.

Description. Specimen orange to reddish after collection, became yellow in alcohol, about 51.8 $\mathrm{cm}$ long (Figs. 6B, 6C). Stem and branches golden with slightly glaucous metallic luster. Colony tree-shaped. Unbranched stem curved, up to $40.5 \mathrm{~cm}$ in arc length and $1.0-2.9 \mathrm{~mm}$ in diameter, emanating in regular 1/4L spiral on the top of a tall (Fig. 6C). Holdfast small and rounded, about $9.8-12.5 \mathrm{~mm}$ in diameter. Distance between adjacent branches in stem $2.0-4.5 \mathrm{~mm}$ long and orthostiche interval 11-16 mm. The first branch internodes 3-7 mm. Branches subdivided 2-7 times and the angle between bifurcating branches particularly obtuse: $18^{\circ}-62^{\circ}$. Terminal branchlets slender, usually whip-like, up to $90 \mathrm{~mm}$ long.

Polyps translucent, $0.9-1.5 \mathrm{~mm}$ long, $0.2-0.4 \mathrm{~mm}$ wide, uniserial spaced $2-5 \mathrm{~mm}$ on the branches by one side, with angle random to the branches. Polyp body base golden, without sclerites (Fig. 6D). Tentacles up to $1.0 \mathrm{~mm}$ in length, became white in alcohol. Three to 20 polyps on terminal branchlets and up to ten polyps in branch internodes. Axial internodal polyps not observed in the stem, where dense mesozooids occurred along the internodes of the stem and branch bases. Mesozooids bud-like shaped, orange in situ and yellowish in alcohol, without sclerites, about $0.3-0.5 \mathrm{~mm}$ wide and up to $0.4 \mathrm{~mm}$ high (Figs. 6A, 6G-6I). 
283

284

285

286

287

288

289

290

291

292

293

294

295

296

297

298

299

300

301

302

303

304

305

306

307

308

309

310

311

312

313

314

315

316

317

318

319

320

321

322

Rods and rod-like scales slender, sometimes one end flat and the other end cylindric, mostly aggregated in the joints between the tentacles and bodies, or longitudinally along the back of the tentacles, with dentate projections at one or both ends and coarse, granular warts on surface, measuring 90-450×15-20 $\mu \mathrm{m}$ (Figs. 6E, 6F, 7A-N). Coenenchyme in branches with a thin pellucid and calcareous layer in outside of the central axis, sometimes with regular scales oriented along branches or without scales on branches. Scales elongated with smooth surface and edges, occasionally with finely serrated edges, usually becoming narrow in middle, rare to absent in coenenchyme, measuring 50-250×12-38 $\mu \mathrm{m}$ (Figs. 7O-W). All sclerites colorless.

Type locality. An unnamed seamount (temporarily named as M2) adjacent to the Mariana Trench with water depths of $298 \mathrm{~m}$.

Etymology. The Latin adjective gracilis (gracile) refers to the gracile stem and branches of this species.

Distribution and Habitat. Found only on the M2 seamount adjacent to the Mariana Trench. Colony attached to a rocky substrate with a small holdfast (Fig. 6A).

Remarks. Among the species possessing 1/4L branching sequence and rods in tentacles, $C$. gracilis sp. nov. mostly resembles $C$. pyramidalis Kükenthal, 1908 in the same branching division and similar length, soft and translucent polyp's body, and the very rare sclerites in coenenchyme (Kükenthal, 1908; Kinoshita, 1913; Cairns, 2001). However, C. gracilis sp. nov. differs from C. pyramidalis by its distinctly longer and unbranched stem, more slender rods with lobed or irregular round ends, nearly smooth and elongated scales in coenenchyme, and the presence of mesozooids (Kükenthal, 1908; Kinoshita, 1913). Compared with congeners, Chrysogorgia gracilis sp. nov. possesses much thinner and smaller polyps, where no sclerites occur at the bases, and rare to absent sclerites in coenenchyme. In contrast, both the polyp body wall and coenenchyme are usually composed of numerous sclerites in other species of Chrysogorgia.

The specimen collected is characteristic in having numerous yellowish mesozooids on the stem internodes and the bases of branches (Figs. 6G-6I). The mesozooids in this species are distinguished from the nematozooids or cnidae existed in some species of Chrysogorgia and Iridogorgia Verrill, 1883 (Kinoshita, 1913; Deichmann, 1936) in size, shape and distribution. The nematozooids are a kind of small protuberances or verrucae distributed on the surface of polyps and coenenchyme on branches, while the mesozooids are similar to polyps in width and are independent on the surface of branches (Fig. 6A).

\section{Genetic distance and phylogenetic analyses}

The mtMutS sequences of the three new species were obtained and deposited in GenBank, with the accession number and the length are as follows: MN510469, $620 \mathrm{bp}$ for Chrysogorgia dendritica sp. nov.; MN510470, 635 bp for $C$. fragilis sp. nov.; and MN510472, 635 bp for $C$. gracilis sp. nov. The alignment dataset comprised 623 nucleotide positions. The present intraspecific distances were calculated based on C. abludo, C. tricaulis, C. artospira, C. averta 
323

324

325

326

327

328

329

330

331

332

333

334

335

336

337

338

339

340

341

342

343

344

345

346

347

348

349

350

351

352

353

354

355

356

357

358

359

360

361

362

and $C$. chryseis populations, and no intraspecific variability was observed for the four species (Table 2). The mtMutS genetic distances among the species of Chrysogorgia range from zero to $2.42 \%$ (Table 2). The genetic distances between the new species $C$. fragilis sp. nov. and congeners are in the range of $0.16 \%-2.26 \%$, and those between $C$. gracilis sp. nov. and congeners are in the range of $0.48 \%-2.10 \%$ (Table 2 ). No genetic variability was observed between dendritica sp. nov. and C. abludo, and the genetic distances between this new species and the rest congeners range from $0.16 \%$ to $2.42 \%$ (Table 2 ).

The ML and BI phylogenetic trees are identical in topology, and thus only the former with the both support values was showed (Fig. 8). The Chrysogorgia species were separated into two main clades (Clade I and II) with high support values. Clade I includes C. binata, C. cf. stellata and $C$. chryseis, and Clade II contains all the rest species. The new species $C$. dendritica sp. nov. and $C$. abludo formed a sister subclade, followed by $C$. fragilis sp. nov. Chrysogorgia gracilis sp. nov. formed a sister subclade with $C$. tricaulis, $C$. artospira, $C$. pinnata, C. averta and the subclade C. ramificans + C. monticola.

\section{Discussion}

Both the morphology and molecular phylogenetic analysis supported the assignment of the three new species to the genus Chrysogorgia. The genetic distance analysis of mtMutS is considered as one of the first steps in an integrative identification of octocorals (McFadden et al., 2011; Pante et al., 2012). In the present study, however, the mtMutS genetic distances within Chrysogorgia are relatively low, and there is no barcoding gap (intraspecific zero vs. interspecific $0-2.42 \%$ ) for species separation. Alternatively, single mutations on mtMutS, corresponding to the genetic distance of ca. $0.16 \%$, can be used to separate Chrysogorgia species (Pante \& Watling, 2012; Pante et al., 2015; this study). Chrysogorgia gracilis sp. nov. and $C$.

fragilis sp. nov. showed at least one single mutation difference from congeners (the corresponding genetic distances in range of $0.16 \%-2.26 \%$; Table 2 ), supporting the establishment of the two new species. Although no genetic variability was observed between $C$. dendritica sp. nov. and C. abludo, the former is distinctly different from the latter by its unique monopodial stem and the amoeba-shaped sclerites at the polyp body bases.

Based on the diagnosis sensu Pante \& Watling, 2012 and Cordeiro et al., 2015, the genus Chrysogorgia includes three branching forms: a single ascending spiral (clockwise or counterclockwise), a fan (planar colony) and two fans emerging from a short main stem (biflabellate colony). Based on the phylogenetic analysis, all the available Chrysogorgia species could be separated into two groups (Clade I and II). All species in Clade I (C. binata, C. cf. stellata and $C$. chryseis) have a bi- or multi-flabellate colony, as in the type species $C$.

desbonni Duchassaing \& Michelotti, 1864. The other species of Chrysogorgia possessing either a bottlebrush-shaped, a planar or a tree-shaped colony formed the Clade II with high support (Fig. 8). Furthermore, the genetic distances between Clade I and II are much higher than the intraclade ones of Clade I ( $1.45 \%-2.42 \%$ vs. $0-0.48 \%$; Table 2$)$. Likely, Clade II represents a new 
363

364

365

366

367

368

369

370

371

372

373

374

375

376

377

378

379

380

381

382

383

384

385

386

387

388

389

390

391

392

393

394

395

396

397

398

399

400

401

402

subgroup of Chrysogorgia or even a new genus. However, only the sequences from 12 of 75 Chrysogorgia species are available for the genetic analysis. Further integrated genetic and morphological analyses are needed to verify this suggestion.

It is worth of note that all the new species possess a tree-shaped colony (monopodial, sympodial), which represent a new colony form in Chrysogorgia. Such a colony occurs also in the paratype NAS204-1 of C. abludo (Pante \& Watling, 2012). Therefore, we add the treeshaped colony to the diagnosis of the genus. Here, we extend the diagnosis of Chrysogorgia on the basis of Pante \& Watling (2012) and Cordeiro et al. (2015): Colony branching usually sympodial, occasionally monopodial, arising from a single ascending spiral (clockwise or counterclockwise, bottlebrush-shaped colony), a fan (planar colony), two fans emerging from a short main stem (biflabellate colony), or an unbranched main stem forming a tree-shaped colony. Axis with a metallic shine, dark to golden in color. Branch subdivided dichotomously or pinnately. Most polyps relatively large to the size of the branches they sit on, few in number and well separated from one another. Sclerites in the form of spindles, rods, scales and rare plates with little ornamentation.

\section{Conclusions}

Based on the morphological and phylogenetic analyses, the newly sampled specimens are recognized as three new species Chrysogorgia dendritica sp. nov., C. fragilis sp. nov. and $C$. gracilis sp. nov. Furthermore, the tree-shaped colony of the new species represents a new branching pattern of Chrysogorgia, and therefore we extend the generic diagnosis.

\section{Acknowledgements}

We thank the assistance of the crew of R/V KeXue and ROV FaXian for sample collection. We also thank Dr. Yang Li for comments on an early manuscript and Mr. Shaoqing Wang for taking the photos on board.

\section{Additional Information and Declarations}

\section{Competing Interests}

The authors declare there are no competing interests.

\section{Author Contributions}

$\mathrm{Yu} \mathrm{Xu}$ conceived and designed the experiments, performed the experiments, analyzed the morphological data, prepared figures and tables, authored drafts of the paper, approved the final draft.

Zifeng Zhan analyzed the molecular data, prepared figures and tables, authored drafts of the paper, approved the final draft.

Kuidong Xu conceived and designed the experiments, reviewed drafts of the paper, approved the final draft. 
403

404

405

406

407

408

409

410

411

412

413

414

415

416

417

418

419

420

421

422

423

424

425

426

427

428

429

430

431

432

433

434

435

436

437

438

439

440

441

442

\section{Data Availability and DNA Deposition}

The following information was supplied regarding data availability:

The specimens described in this study are deposited in the Marine Biological Museum of

Chinese Academy of Sciences (MBMCAS) at Institute of Oceanology, Qingdao, China. Voucher

ID for Chrysogorgia dendritica is MBM286354; vouchers ID for the holotype and paratypes

of Chrysogorgia fragilis are MBM286351 and MBM286352, respectively; Voucher ID for

Chrysogorgia gracilis is MBM286350. The mtMuts sequences of the new species are available at NCBI GenBank: MN510469, MN510470 and MN510472, respectively.

\section{New Species Registration}

The following information was supplied regarding the registration of a newly described species: Publication LSID: urn:lsid:zoobank.org:pub:00D5E053-EFF8-4142-8D16-AAFC17D028E2. Chrysogorgia dendritica sp. nov. LSID: urn:lsid:zoobank.org:act:F0050AD3-9E65-4B03-8D262C687018DCAD, Chrysogorgia fragilis sp. nov. LSID: urn:1sid:zoobank.org:act:562CFDA788F5-4D81-8FE5-BDE1F56A3EEC, and Chrysogorgia gracilis sp. nov. LSID:

urn:1sid:zoobank.org:act:F557CE43-D43C-4E5F-86C1-3EFE330A9443.

\section{Funding}

This work was supported by the Key Program of National Natural Science Foundation of China (No. 41930533), the Strategic Priority Research Program of the Chinese Academy of Sciences (XDA19060401), the Science \& Technology Basic Resources Investigation Program of China (2017FY100804) and the Senior User Project of RV KEXUE.

\section{References}

Alfaro ME, Zoller S, Lutzoni F. 2003. Bayes or Bootstrap? A simulation study comparing the performance of Bayesian Markov chain Monte Carlo sampling and bootstrapping in assessing phylogenetic confidence. Molecular Biology and Evolution 20(2): 255-266.

Bayer FM, Grasshoff M, Verseveldt J. 1983. Illustrated Trilingual Glossary of Morphological and Anatomical Terms Applied to Octocorallia. E. J. Brill/Dr. W. Backhuys, Leiden, 75 pp.

Cairns SD. 2001. Studies on western Atlantic Octocorallia (Gorgonacea: Ellisellidae). Part 1: The genus Chrysogorgia Duchassaing \& Michelotti, 1864. Proceedings of the Biological Society of Washington 114(3): 746-787. https://doi. org/10.2988/0006-324X (2007)120[243: SOWAOG] 2.0.CO;2

Cairns SD. 2018. Deep-Water Octocorals (Cnidaria, Anthozoa) from the Galápagos and Cocos Islands. Part 1: Suborder Calcaxonia. ZooKeys 729: 1-46. https://doi.org/10.3897/zookeys.729.21779

Cordeiro RTS, Castro CB, Pérez CD. 2015. Deep-water octocorals (Cnidaria: Octocorallia) from Brazil: family Chrysogorgiidae Verrill, 1883. Zootaxa 4058(1): 81-100. https://doi. org/10.11646/zootaxa.4058.1.4 
443

444

445

446

447

448

449

450

451

452

453

454

455

456

457

458

459

460

461

462

463

464

465

466

467

468

469

470

471

472

473

474

475

476

477

478

479

480

481

482

Darriba D, Taboada GL, Doallo R, Posada D. 2012. jModelTest 2: more models, new heuristics and parallel computing. Nature Methods 9: 772.

Deichmann, E. 1936. The Alcyonaria of the western part of the Atlantic Ocean. Memoirs of the Museum of Comparative Zoology, Harvard, 53, 1-317.

Duchassaing P, Michelotti J. 1864. Supplément au mémoire sur les coralliaires des Antilles. Memorie della Reale Accademia delle Scienze di Torino 2(23): 97-206

Ehrenberg CG. 1834. Beiträge zur physiologischen Kenntniss der Corallenthiere im allgemeinen, und besonders des rothen Meeres, nebst einem Versuche zur physiologischen Systematik derselben. Abhandlungen der Königlichen Akademie der Wissenschaften, Berlin 1: $225-380$.

Grasshoff M. 1999. The shallow-water gorgonians of New Caledonia and adjacent islands (Coelenterata, Octocorallia). Senckenbergiana biologica 78: 1-121.

Guindon S, Dufayard JF, Lefort V, Anisimova M, Hordijk W, Gascuel O. 2010. New algorithms and methods to estimate maximum-likelihood phylogenies: assessing the performance of PhyML 3.0. Systematic Biology 59: 307-321.

Haeckel E. 1866. Generelle morphologie der Organismen, vol. 2. Verlag von Georg Reimer, Berlin.

Hall TA. 1999. BioEdit: a user-friendly biological sequence alignment editor and analysis program for Windows 95/98/NT. Nucleic Acids Symposium Series, 41, 95-98.

Herrera S, Baco A, Sánchez JA. 2010. Molecular systematics of the bubblegum coral genera (Paragorgiidae, Octocorallia) and description of a new deep-sea species. Molecular Phylogenetics and Evolution 55(1): 123-135.

Hillis DM, Bull JJ. 1993. An empirical test of bootstrapping as a method for assessing confidence in phylogenetic analysis. Systematic Biology 42(2): 182-192.

Katoh K, Standley DM. 2013. MAFFT Multiple Sequence Alignment Software version 7: improvements in performance and usability. Molecular Biology and Evolution 30: 772-780.

Kinoshita K. 1913. Studien über einige Chrysogorgiiden Japans. Journal of the College of Science, Tokyo Imperial University 33(2): 47 pp.

Kükenthal, W. 1908. Diagnosen neuer Gorgoniden aus der Gattung Chrysogorgia (6. Mitteilung). Zoologischer Anzeiger 33(21): 704-708.

Lamouroux JVF. 1812. Extrait d'un mémoire sur la classification des polypiers coralligènes non entièrement piérreux. Nouveau Bulletin des Sciences, Société Philomathique de Paris 3(63): 181-188.

McFadden CS, Benayahu Y, Pante E, Thoma JN, Nevarez PA, France SC. 2011. Limitations of mitochondrial gene barcoding in Octocorallia. Molecular Ecology Resources 11(1):1931.

Pante E, France SC. 2010. Pseudochrysogorgia bellona n. gen., sp. nov.: a new genus and species of chrysogorgiid octocoral (Coelenterata, Anthozoa) from the Coral Sea. Zoosystema 32(4): 595-612. https://doi.org/10.5252/z2010n4a4 
483

484

485

486

487

488

489

490

491

492

493

494

495

496

497

498

499

500

501

502

503

504

505

506

507

508

509

510

511

512

513

514

515

516

517

Pante E, Watling L. 2012. Chrysogorgia from the New England and Corner Seamounts: Atlantic-Pacific connections. Journal of the Marine Biological Association of the United Kingdom 92(5): 911-927. http://doi.org/10.1017/S0025315411001354

Pante E, Abdelkrim J, Viricel A, Gey D, France SC, Boisselier MC, Samadi S. 2015. Use of rad sequencing for delimiting species. Heredity 114: 450-459.

Pante E, France SC, Couloux A, Cruaud C, McFadden CS, Samadi S, Watling L. 2012. Deep-sea origin and in-situ diversification of chrysogorgiid octocorals. PLoS ONE 7(6): e38357.

Ronquist FR, Huelsenbeck JP. 2003. Mrbayes 3: Bayesian phylogenetic inference under mixed models. Bioinformatics 19: 1572-1574.

Sánchez JA, Lasker HR, Taylor DJ. 2003. Phylogenetic analyses among octocorals (Cnidaria): mitochondrial and nuclear DNA sequences (lsu-rRNA, 16S and ssu-rRNA, 18S) support two convergent clades of branching gorgonians. Molecular Biology and Evolution 29: 3142.

Tamura K, Stecher G, Peterson D, Filipski A, Kumar S. 2013. MEGA6: Molecular Evolutionary Genetics Analysis Version 6.0. Molecular Biology and Evolution 30(12): 2725-2729.

Verrill AE. 1883. Report on the Anthozoa, and on some additional species dredged by the "Blake" in 1877-1879, and by the U.S. Fish Commission steamer "Fish 126 Hawk" in 1880-82. Bulletin of the Museum of Comparative Zoology 11: 1-72.

Versluys J. 1902. Die Gorgoniden der Siboga-Expedition. 1. Die Chrysogorgiiden. Siboga Expeditie 13: 1-120.

Watling L, France S, Pante E, Simpson A. 2011. Biology of Deep-Water Octocorals. In: Lesser, M. (Ed), Advances in Marine Biology. Elsevier Academic press, London, pp. 41122.

Yang Li, Zifeng Zhan, Kuidong Xu. 2017. Morphology and molecular phylogeny of Paragorgia rubra sp. nov. (Cnidaria: Octocorallia), a new bubblegum coral species from a seamount in the tropical Western Pacific. Chinese Journal of Oceanology and Limnology 35(4): 803-814. http: //dx.doi.org/10.1007/s00343-017-5320-5

Yu Xu, Yang Li, Zifeng Zhan, Kuidong Xu. 2019. Morphology and phylogenetic analysis of two new deep-sea species of Chrysogorgia (Cnidaria, Octocorallia, Chrysogorgiidae) from Kocebu Guyot (Magellan seamounts) in the Pacific Ocean. Zookeys 881: 91-107. https://doi.org/10.3897/zookeys.881.34759 


\section{Table 1 (on next page)}

Morphological comparisons between C. averta , C. abludo , C. dendritica sp. nov., C. fragilis sp. nov. and C. gracilis sp. nov. 
1 Table 1 Morphological comparisons between $C$. averta, $C$. abludo, $C$. dendritica sp. nov., $C$.

2 fragilis sp. nov. and $C$. gracilis sp. nov.

\begin{tabular}{|c|c|c|c|c|c|}
\hline Characters/species & C. averta & C. abludo & $\begin{array}{l}\text { C. fragilis sp. } \\
\text { nov. }\end{array}$ & $\begin{array}{l}\text { C. dendritica } \\
\text { sp. nov. }\end{array}$ & $\begin{array}{l}\text { C. gracilis } \mathrm{sp} . \\
\text { nov. }\end{array}$ \\
\hline Group type & A & A & A & A & A \\
\hline Colony shape & $\begin{array}{l}\text { bottlebrush- } \\
\text { shaped }\end{array}$ & $\begin{array}{l}\text { bottlebrush-shaped } \\
\text { or tree-shaped }\end{array}$ & tree-shaped & tree-shaped & tree-shaped \\
\hline Branching sequence & $3 / 8 \mathrm{~L}$ & $1 / 3,1 / 4 \mathrm{~L}$, irregular & $1 / 3 \mathrm{~L}$ & $1 / 3 \mathrm{~L}$ & $1 / 4 \mathrm{~L}$ \\
\hline $\begin{array}{l}\text { Interbranch distance } \\
(\mathrm{mm})\end{array}$ & $9-13$ & $4.3-15.0$ & $15-22$ & $16-22$ & $2.0-4.5$ \\
\hline $\begin{array}{l}\text { Orthostiche interval } \\
(\mathrm{mm})\end{array}$ & $75-78$ & No data & $50-65$ & $50-55$ & $11-16$ \\
\hline $\begin{array}{l}\text { First branch internode } \\
(\mathrm{mm})\end{array}$ & $13-19$ & $6.1-16.0$ & $15-22$ & $15-20$ & $3-7$ \\
\hline Polyps on internodes & $0-2$ & $1-2$ & $0-4$ & $1-5$ & $1-10$ \\
\hline $\begin{array}{l}\text { Polyps on terminal } \\
\text { branchlets }\end{array}$ & $1-3$ & $1-6$ & $1-10$ & $1-6$ & $3-20$ \\
\hline Polyps height (mm) & $1.1-1.9$ & $0.8-2.2$ & $2.0-4.0$ & 3.0 & $0.9-1.5$ \\
\hline $\begin{array}{l}\text { Sclerites in } \\
\text { coenenchyme }\end{array}$ & $\begin{array}{l}\text { rods and } \\
\text { scales }\end{array}$ & $\begin{array}{l}\text { small rugged } \\
\text { scales }\end{array}$ & $\begin{array}{l}\text { elongate flat } \\
\text { scales }\end{array}$ & $\begin{array}{l}\text { flat and lobed } \\
\text { scales }\end{array}$ & $\begin{array}{l}\text { elongated } \\
\text { scales with } \\
\text { smooth } \\
\text { surface and } \\
\text { edges }\end{array}$ \\
\hline Sclerites in body wall & $\begin{array}{l}\text { scales and } \\
\text { rods }\end{array}$ & scales and rods & $\begin{array}{l}\text { scales, rods } \\
\text { and spindles }\end{array}$ & $\begin{array}{l}\text { plates, scales, } \\
\text { rods and } \\
\text { spindles }\end{array}$ & $\begin{array}{l}\text { scales and } \\
\text { rods }\end{array}$ \\
\hline Sclerites in tentacles & rods & rods & rods & rods & $\begin{array}{l}\text { scales and } \\
\text { rods }\end{array}$ \\
\hline Distribution & $\begin{array}{l}\text { North } \\
\text { Atlantic }\end{array}$ & North Atlantic & $\begin{array}{l}\text { Western } \\
\text { Pacific }\end{array}$ & Western Pacific & $\begin{array}{l}\text { Western } \\
\text { Pacific }\end{array}$ \\
\hline References & $\begin{array}{l}\text { Pante \& } \\
\text { Watling } 2012\end{array}$ & $\begin{array}{l}\text { Pante \& Watling } \\
2012\end{array}$ & Present study & Present study & Present study \\
\hline
\end{tabular}


Table 2 (on next page)

Interspecific and intraspecific uncorrected pairwisedistances at mtMutS of species of Chrysogorgia. 
1 Table 2 Interspecific and intraspecific uncorrected pairwise distances at mtMutS of species of Chrysogorgia.

\begin{tabular}{|c|c|c|c|c|c|c|c|c|c|c|c|c|c|c|}
\hline & & 1 & 2 & 3 & 4 & 5 & 6 & 7 & 8 & 9 & 10 & 11 & 12 & 13 \\
\hline & Chrysogorgia gracilis sp. nov. & & & & & & & & & & & & & \\
\hline 1 & MN510472 & - & & & & & & & & & & & & \\
\hline 2 & C. dendritica sp. nov. MN510469 & $0.97 \%$ & - & & & & & & & & & & & \\
\hline 3 & C. fragilis sp. nov. MN510470 & $1.13 \%$ & $0.16 \%$ & - & & & & & & & & & & \\
\hline 4 & C. abludo GQ180139, JN227999 & $0.97 \%$ & 0 & $0.16 \%$ & 0 & & & & & & & & & \\
\hline & C. tricaulis JN227998, JN227990, & & & & & & & & & & & & & \\
\hline 5 & JN227991, GQ180123-31, EU268056 & $0.65 \%$ & $0.97 \%$ & $0.81 \%$ & $0.97 \%$ & 0 & & & & & & & & \\
\hline 6 & C. artospira GQ180132-5, GQ353317 & $0.48 \%$ & $0.81 \%$ & $0.65 \%$ & $0.81 \%$ & $0.16 \%$ & 0 & & & & & & & \\
\hline 7 & C. pinnata JN227988 & $0.48 \%$ & $0.81 \%$ & $0.65 \%$ & $0.81 \%$ & $0.16 \%$ & 0 & - & & & & & & \\
\hline 8 & C. averta $\mathrm{KC} 788265, \mathrm{GQ} 180136$ & $0.81 \%$ & $1.13 \%$ & $0.97 \%$ & $1.13 \%$ & $0.48 \%$ & $0.32 \%$ & $0.32 \%$ & 0 & & & & & \\
\hline 9 & C. ramificans MK 431863 & $1.13 \%$ & $1.45 \%$ & $1.29 \%$ & $1.45 \%$ & $0.81 \%$ & $0.65 \%$ & $0.65 \%$ & $0.97 \%$ & - & & & & \\
\hline 10 & C. monticola JN227989 & $1.13 \%$ & $1.45 \%$ & $1.29 \%$ & $1.45 \%$ & $0.81 \%$ & $0.65 \%$ & $0.65 \%$ & $0.97 \%$ & $0.32 \%$ & - & & & \\
\hline 11 & C. binata MK431862 & $2.10 \%$ & $2.42 \%$ & $2.26 \%$ & $2.42 \%$ & $1.77 \%$ & $1.61 \%$ & $1.61 \%$ & $1.94 \%$ & $2.26 \%$ & $2.26 \%$ & - & & \\
\hline 12 & C. cf. stellata JN227920 & $1.94 \%$ & $2.26 \%$ & $2.10 \%$ & $2.26 \%$ & $1.61 \%$ & $1.45 \%$ & $1.45 \%$ & $1.77 \%$ & $2.10 \%$ & $2.10 \%$ & $0.16 \%$ & - & \\
\hline 13 & C. chryseis JN227992, DQ297421 & $2.10 \%$ & $2.42 \%$ & $2.26 \%$ & $2.42 \%$ & $1.77 \%$ & $1.61 \%$ & $1.61 \%$ & $1.94 \%$ & $2.26 \%$ & $2.26 \%$ & $0.48 \%$ & $0.32 \%$ & 0 \\
\hline
\end{tabular}


Figure 1

Sampling sites on a seamount (M2) adjacent to the Mariana Trench and the Kocebu Guyot inthe Western Pacific Ocean.

(Map credit: ODV at http://odv.awi.de/, plotted by Yu Xu).

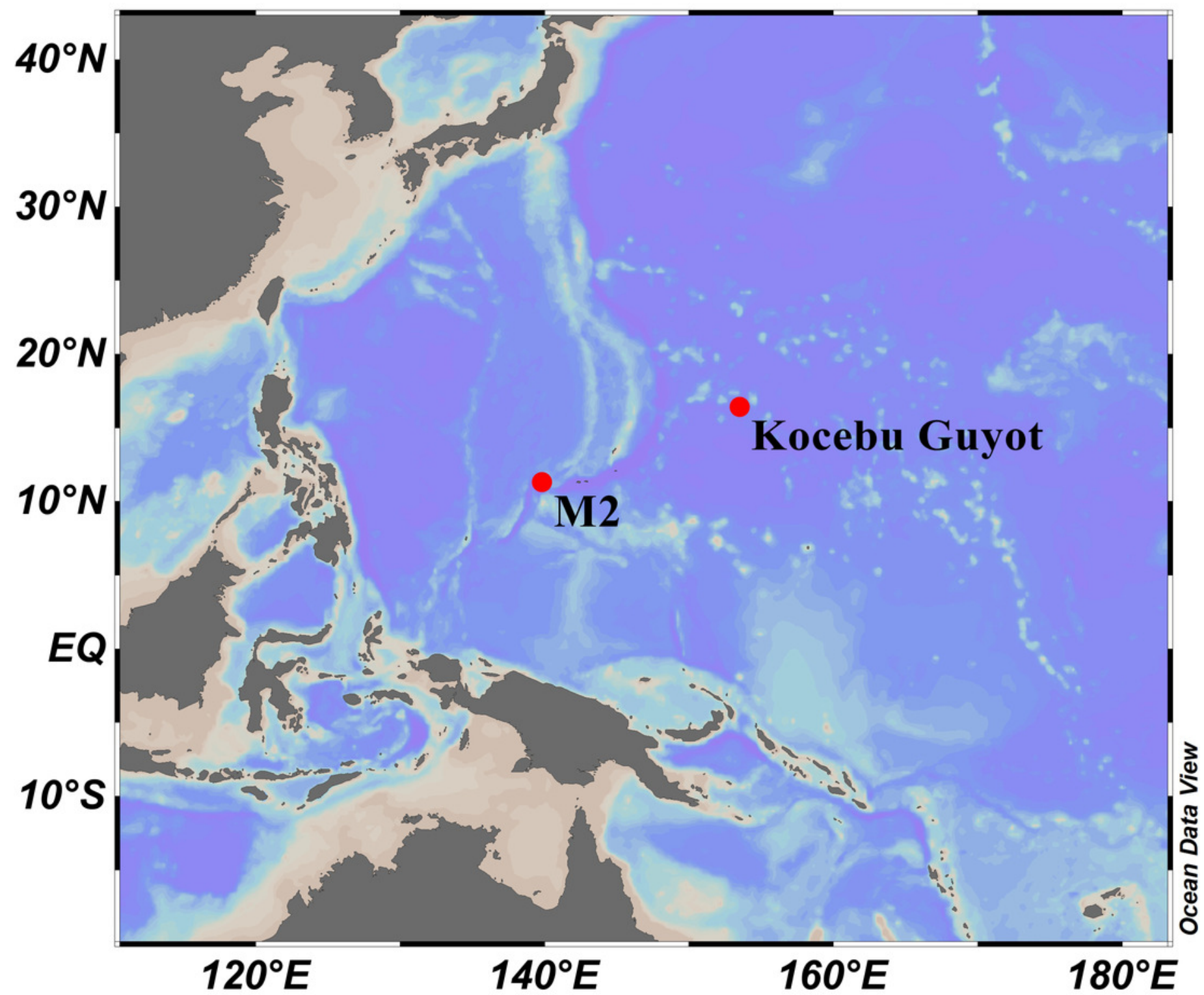




\section{Figure 2}

The external morphology and polyps of Chrysogorgia dendritica sp. nov..

(A) The holotype in situ; (B) The holotype immediately after collection; (C) A single polyp under light microscope; (D) Single polyp under SEM. (E) Tentacles with rods under SEM (Photo credit: Yu Xu and Shaoqing Wang).
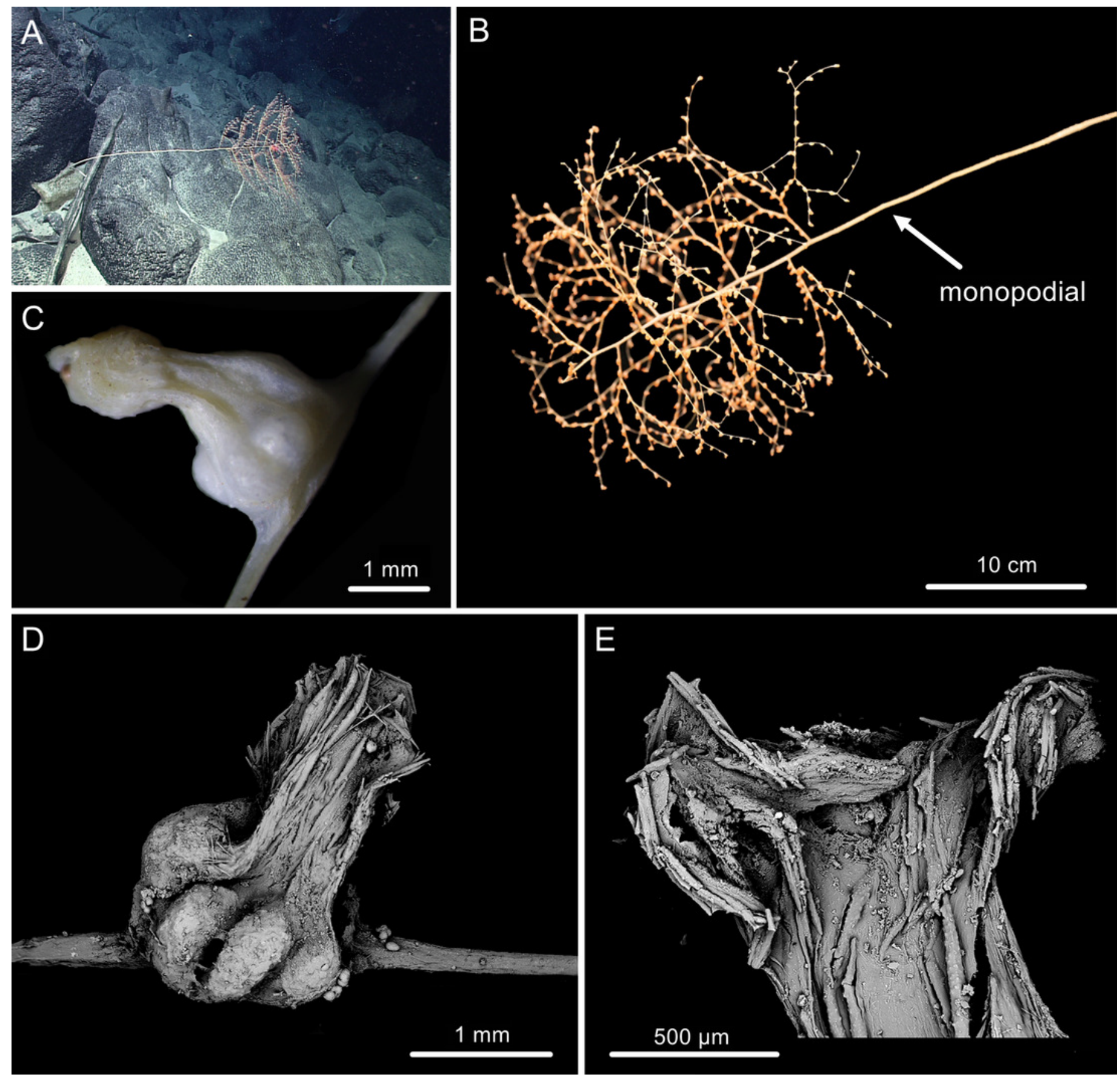
Figure 3

Sclerites of Chrysogorgia dendritica sp. nov. .

(A-G) Sclerites of the polyp neck. (H-M) Sclerites in the back of tentacles; (N-X) Sclerites at the body base; (Y-GG) Sclerites in coenenchyme. Scale bars: A-G and H-M, N-X and Y-GG at the same scale, respectively (Image credit: Yu Xu). 


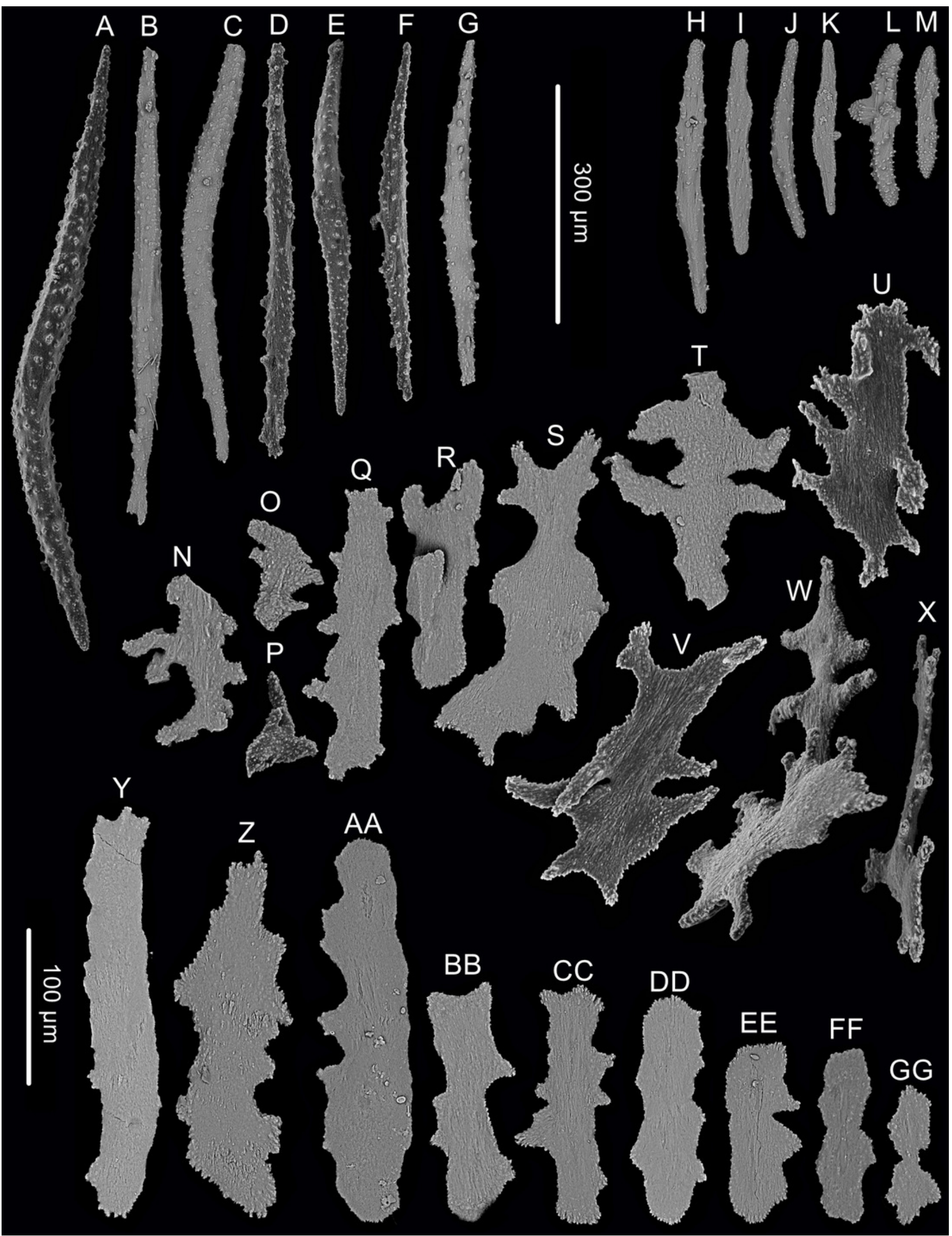


Figure 4

The external morphology and polyps of Chrysogorgia fragilis sp.nov..

(A) The holotype in situ. Laser dots spaced at $33 \mathrm{~cm}$ used for measuring dimensions; (B) The paratype in situ; (C) The holotype immediately after collection; (D) The paratype after fixation; (E, F) A single polyp under light microscope; (G-I) Three polyps under SEM (Photo credit: Yu Xu and Shaoqing Wang). 

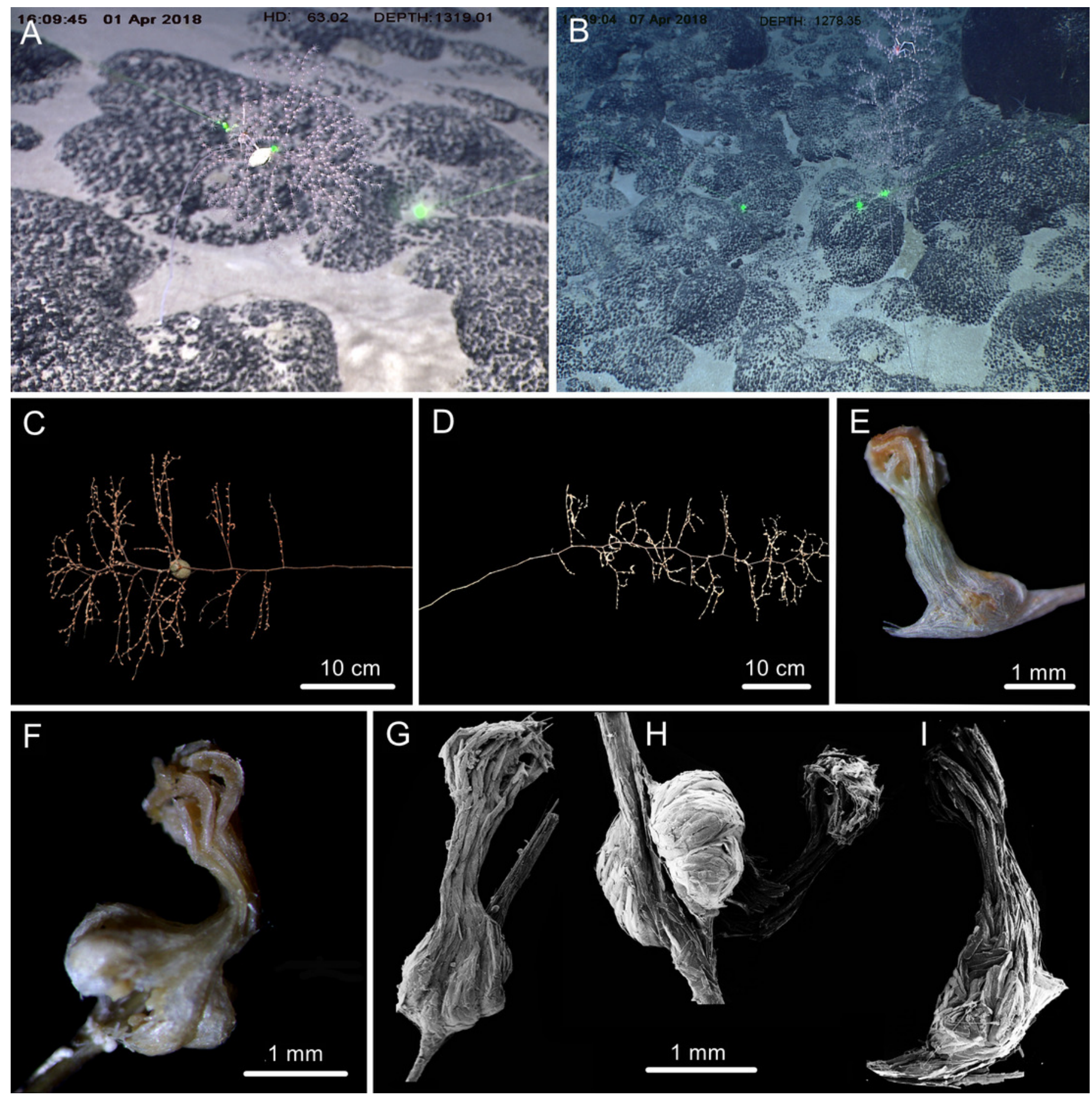
Figure 5

Sclerites of Chrysogorgia fragilis sp.nov..

(A-G) Sclerites of the polyp neck; (H-L) Sclerites in the back of tentacles; (M-V) Sclerites at the expanded polyp body base; (W-EE) Sclerites in coenenchyme. Scale bar: all at the same scale (Image credit: Yu Xu). 


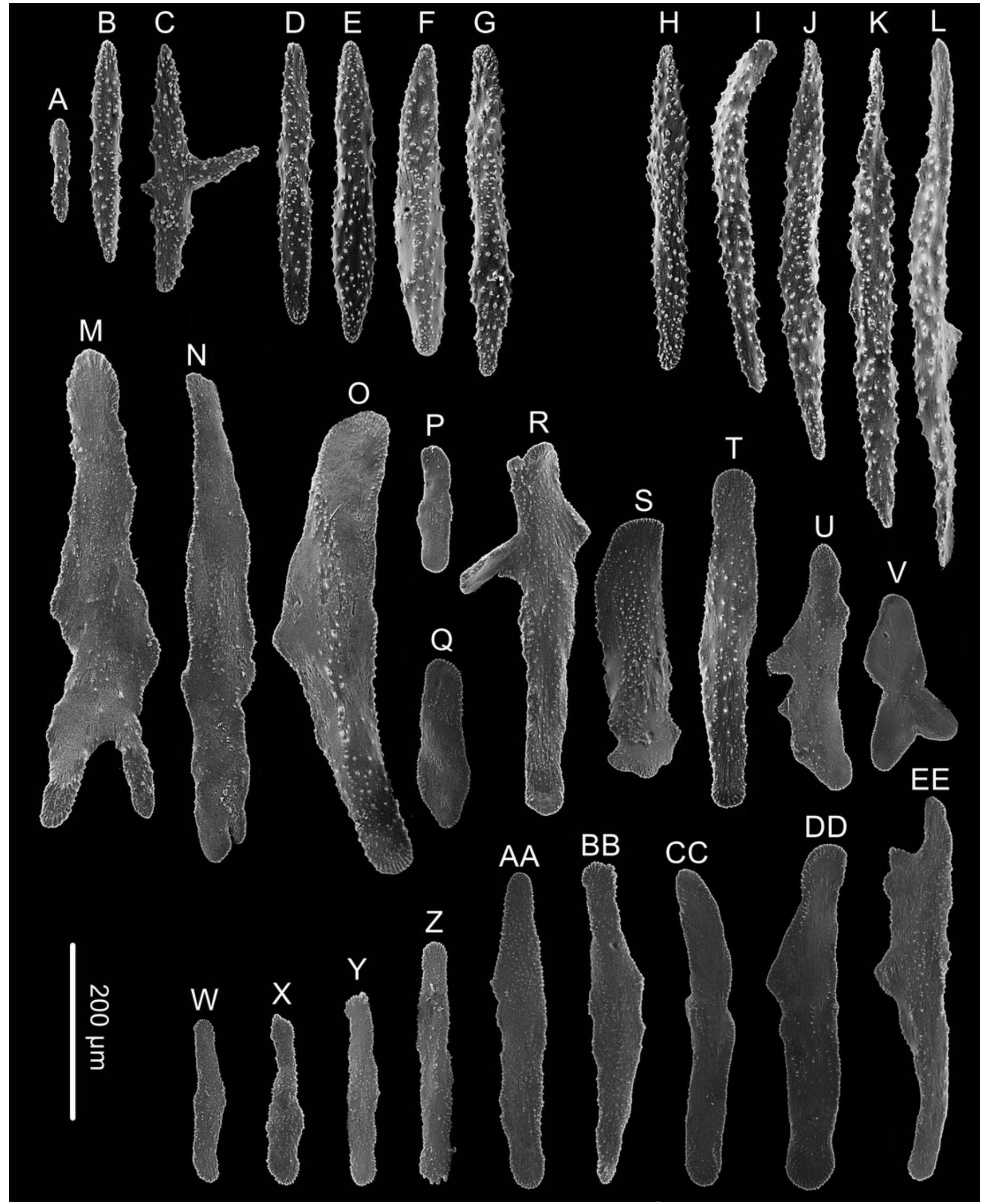




\section{Figure 6}

The external morphology and polyps of the holotype of Chrysogorgia gracilis sp. nov..

(A-C) The holotype in situ (A) and after collection (B) and fixation (C); Laser dots spaced at 33 cm used for measuring dimensions; (D) A single polyp under light microscope; (E) A single polyp under SEM; (F) Tentacles under SEM; (G) Mesozooids at the base of branch under light microscope; (H) Four mesozooids under SEM; (I) A single mesozooid under SEM (Photo credit: Yu Xu and Shaoqing Wang). 

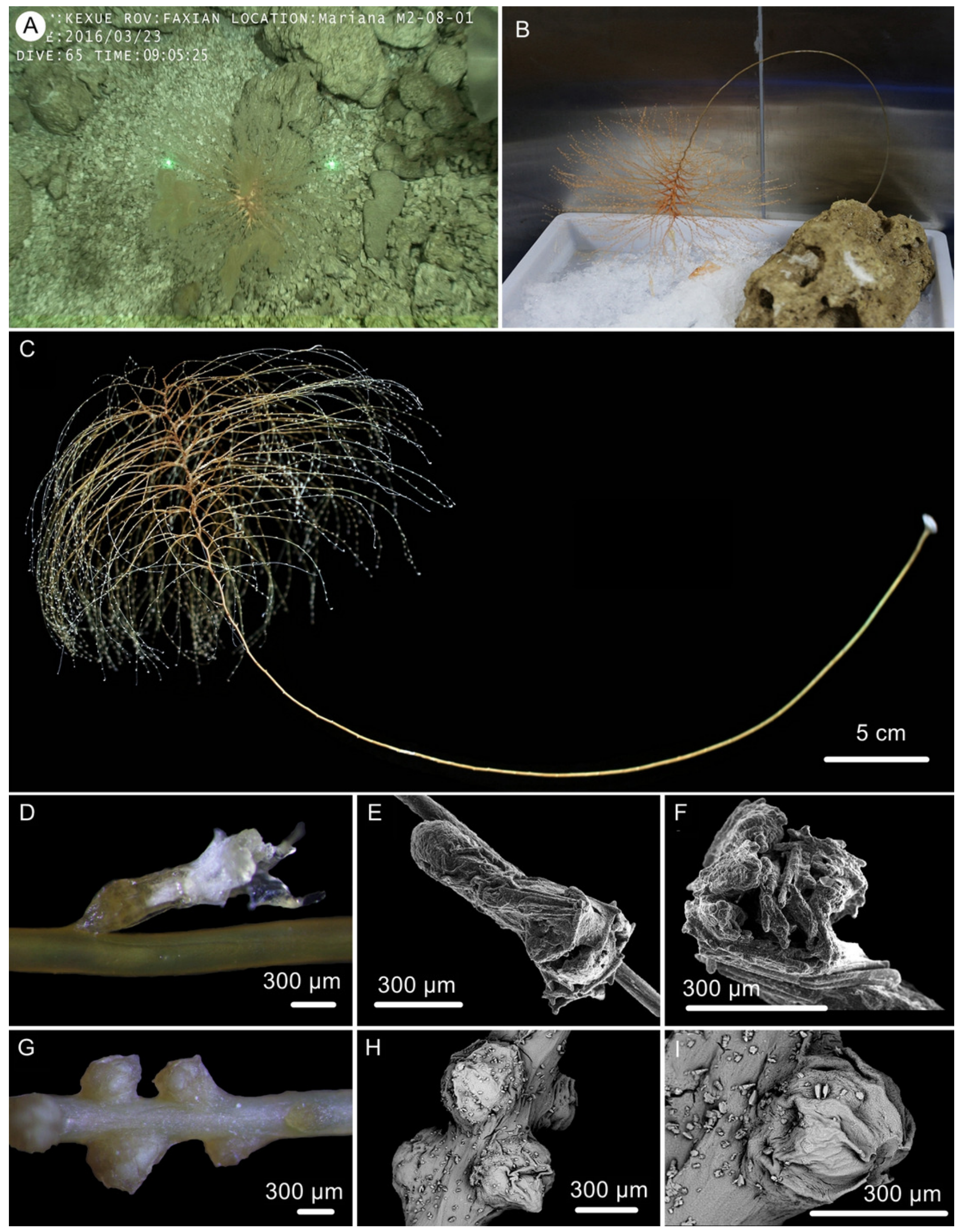
Figure 7

Sclerites of Chrysogorgia gracilis sp. nov..

(A-N) Sclerites in tentacles and at the bases of tentacles; (O-W) Sclerites in coenenchyme. Scales bars: all at the same scale (Image credit: Yu Xu).

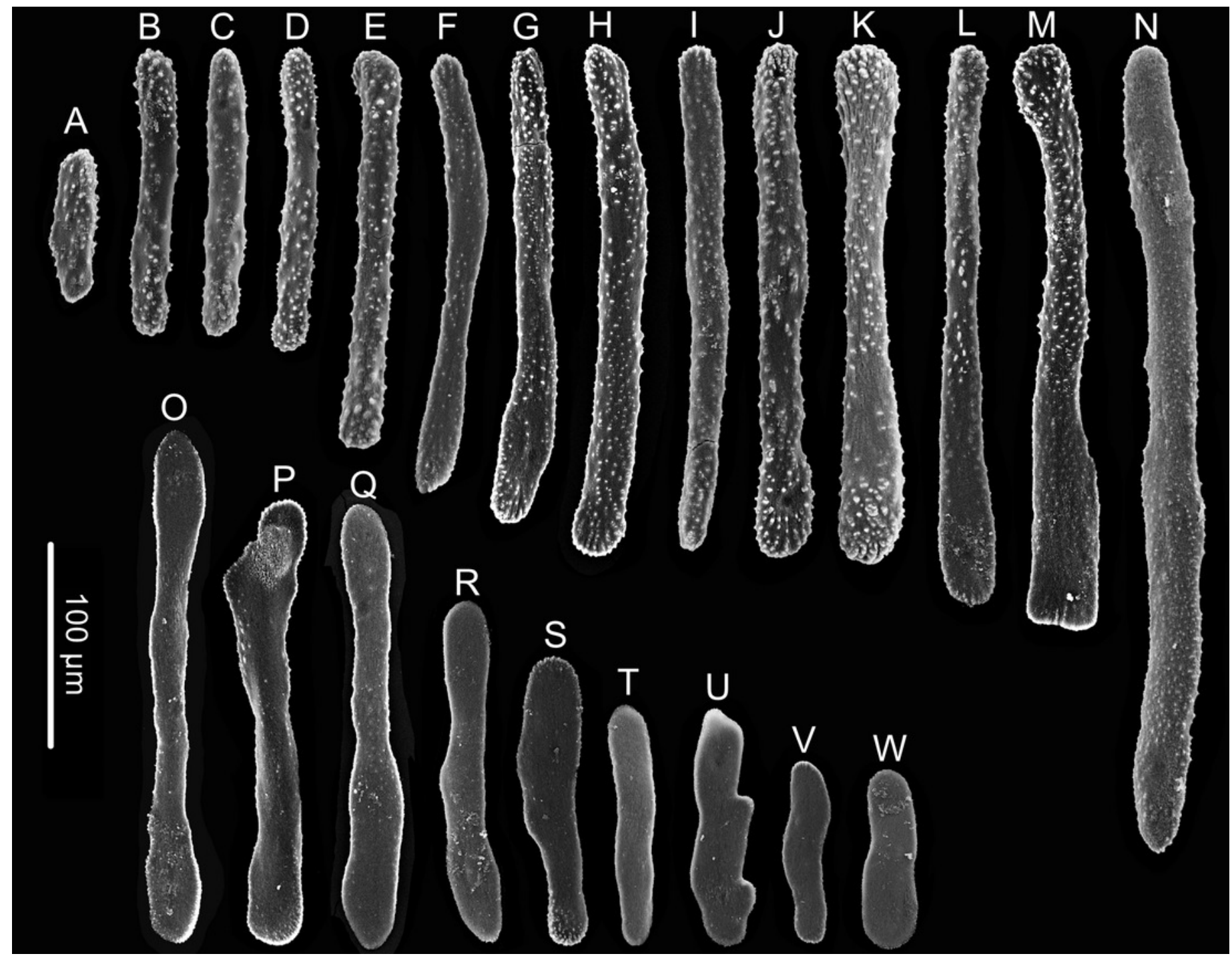


Figure 8

Maximum likelihood (ML) tree inferred from themtMutS sequences of Chrysogorgia andthe related species sequences.

The Bayesian inference (BI) tree and the ML tree are identical in topology. Node support is as follows: BI posterior probability / ML bootstrap. Newly sequenced species are in bold (Image credit: Zifeng Zhan).

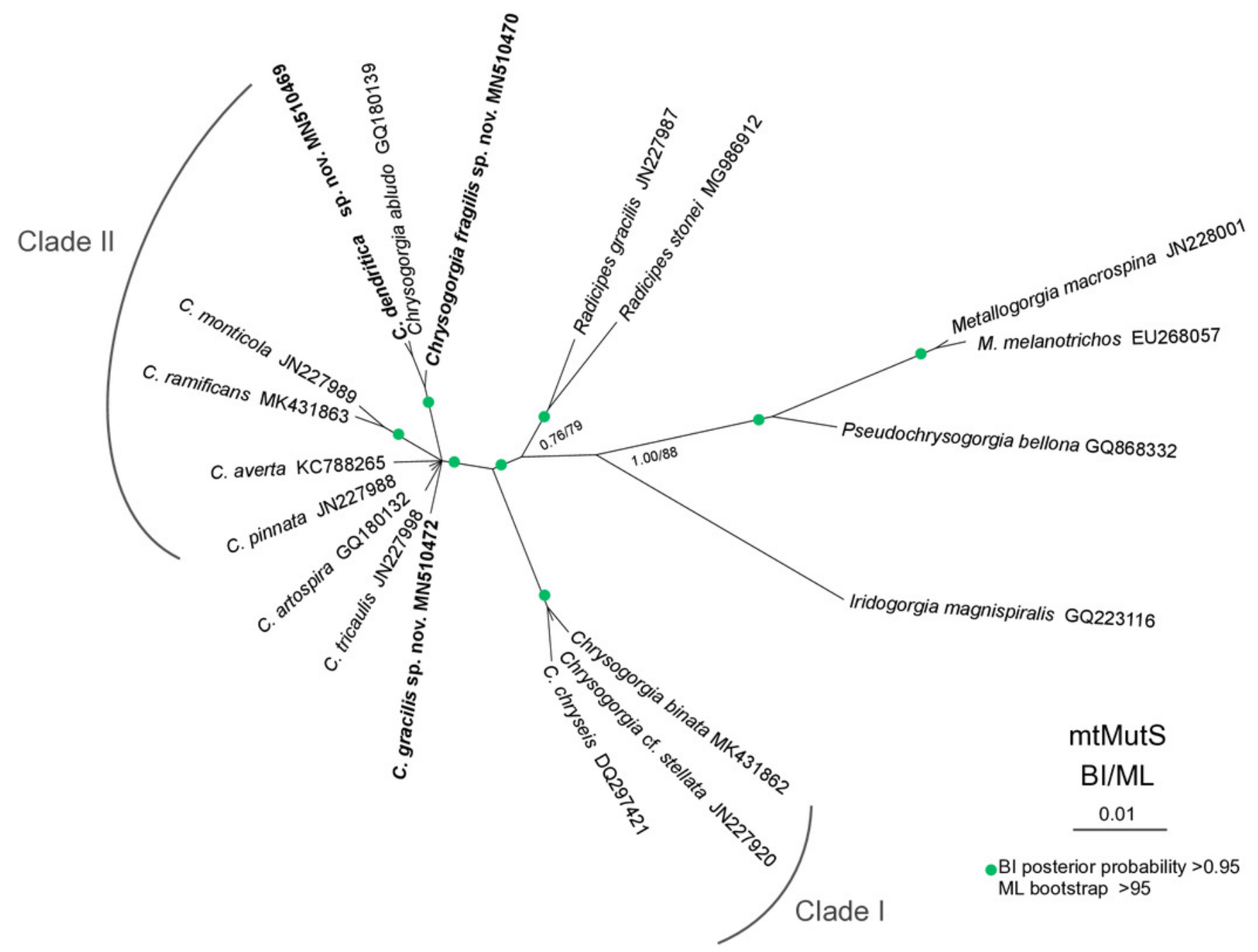

